\title{
In Search of Monsters to Destroy: NATO's Prosecution of the Kosovo Intervention in the Just War Tradition
}

\author{
Scott N. Duryea
}

\begin{abstract}
Many commentators believe that the NATO bombing campaign in the spring of 1999 in Kosovo answered the call for ethical humanitarian intervention. NATO responded with an aerial bombardment to stop Serbian aggression. Some analysts argue that the NATO response was destructive, costly, and a humanitarian disaster. Others proclaim it as appropriate, necessary, and just. On the specific ethical viewpoint, the just war theory, which has evolved throughout centuries to form the ethical justification for military action, offers strict criteria at the most basic level. Numerous scholars have already touched upon the ethical criteria for going to war. There remains, however, a gap in the literature regarding NATO behavior during the bombing campaign. I argue that, on many occasions, NATO operations violated jus in bello criteria, making the bombing campaign inhumane and ethically inexcusable.
\end{abstract}

Keywords: Just War Theory, Great Power Competition, Kosovo, Jus In Bello, Ethics

\section{En busca de monstruos para destruir: el enjuiciamiento de la OTAN de la intervención de Kosovo en la tradición de la guerra justa}

\section{RESUMEN}

Muchos comentaristas creen que la campaña de bombardeos de la OTAN en la primavera de 1999 en Kosovo respondió al llamado a una intervención humanitaria ética. La OTAN respondió con un bombardeo aéreo para detener la agresión serbia. Algunos analistas sostienen que la respuesta de la OTAN fue destructiva, costosa y un desastre humanitario. Otros lo proclaman como apropiado, necesario y justo. Desde el punto de vista ético específico, la teoría de la guerra justa, que ha evolucionado a lo largo de los siglos para constituir la justificación ética de la acción militar, ofrece criterios estrictos 
en el nivel más básico. Numerosos estudiosos ya se han referido a los criterios éticos para ir a la guerra. Sin embargo, queda un vacío en la literatura sobre el comportamiento de la OTAN durante la campaña de bombardeos. Sostengo que, en muchas ocasiones, las operaciones de la OTAN violaron los criterios del jus in bello, haciendo que la campaña de bombardeos fuera inhumana y éticamente inexcusable.

Palabras clave: Teoría de la guerra justa, Gran Competencia de Poder, Kosovo, Jus In Bello, Ética

\section{搜寻并摧毁怪物: 北约以正义战争 传统的方式实施科索沃干预}

\section{摘要}

许多评论者认为, 北约于 1999 年春季在科索沃执行的轰炸行 动响应了对伦理人道主义干预的呼吁。北约用空袭阻止塞尔 维亚的侵略。一些分析师主张, 北约的响应具有破坏性且代 价巨大, 并且是一次人道主义灾难。其他人则认为北约的响 应是合适的、必要的且正义的。从具体的伦理角度来看, 正 义战争理论（经过几百年的演变形成了军事行动的伦理支 持）提供了最基本层面的严格标准。许多学者已研究了诉诸 战争的伦理标准。不过，就轰炸行动 “期间” 的北约行为而 言, 相关研究仍然不足。我论证认为, 在许多情况下, 北约 行动违反了战时法, 让轰炸行动变得不人道且在伦理上不可 饶恕。

关键词: 正义战争理论, 大国竞争, 科索沃, 战时法, 伦理 学

\section{Introduction}

${ }^{\text {"}} \mathrm{H}$ umanitarian war" reads as a contradiction in terms. To use lethal force for humane reasons seems illogical. But, for centuries, and with the exception of pacifists, philosophers and theolo- gians alike have long held that force is ethically acceptable under certain strict conditions. Indeed, it is an ethical duty in some instances to use force to protect individuals. Ethical, as differentiated from legal, action affects the individual conscience, and is not subject to international legal scrutiny. But, 
states often appeal to ethical authority to gain popular support for the use of military force. And, many commentators believe that the NATO bombing campaign in the spring of 1999 in Kosovo answered this call for ethical intervention. Serbian forces had been increasingly retaliating against Kosovo Liberation Army (KLA) attacks against Serb police forces and presence within Kosovo, alarming the West of a potential massacre waiting to happen. NATO responded with an aerial bombardment to stop Serbian aggression. Some analysts argue that the NATO response was disproportionate. Others proclaim it as appropriate, necessary, and just. How should one interpret the intervention? This article examines the Kosovo intervention through the lens of just war theory. The Catholic Church as well as other ethical authorities recognize the necessity of war in particular circumstances. Just war theory lays out the conditions required to ethically justify military action.

Scholars, including Robert Keohane, consider NATO's humanitarian intervention illegal yet geopolitically necessary. ${ }^{1}$ President Bill Clinton described the war as "an attack by tanks and artillery on a largely defenseless people whose leaders already have agreed to peace." ${ }^{2}$ British Prime Minister Tony Blair defended intervention "to avert what would otherwise be a humanitarian disaster in Kosovo." Others, mainly in the pacifist camp, saw NATO's intervention as destructive, costly, and a humanitarian disaster. Scholars and world leaders have judged the intervention according to different measures. Tenets of international law and theories of foreign policy strategy can offer useful yet opposing perspectives on the appropriate course of action. On the specific ethical question, however, just war theory, which has been developed throughout centuries to formulate the ethical justification for military action, offers strict criteria at the most basic level and offers moralists a framework to analyze military conflict. Numerous scholars have already touched upon the ethical criteria for going to war. There remains, however, a gap in the literature regarding NATO behavior during the bombing campaign. On many occasions, NATO operations violated just war jus in bello criteria, making the military action inhumane and ethically inexcusable.

\section{The Just War Tradition}

he just war (Bellum iustum) tra-
dition has deep roots. One of the
first elaborations of the tenets of just war appeared in the Indian epic Mahabharata around 400 BC. It laid out elementary conceptions of the princi-

1 J.L. Holzgrefe and Robert O. Keohane, eds., Humanitarian Intervention: Ethical, Legal and Political Dilemmas (Cambridge: Cambridge University Press,2003), 1.

2 Bill Clinton, "Statement on Kosovo," Miller Center, University of Virginia (March 24, 1999), http:// millercenter.org/president/speeches/detail/3932.

3 Tony Blair, "Blair: 'We Must Act - to Save Thousands of Innocent Men, Women and Children"' The Guardian March 23, 1999. 
ples of proportionality, just means, just cause, and just conduct. ${ }^{4}$ Augustine of Hippo and Thomas Aquinas further expanded upon the early Indian conception. Augustine posited that one could simultaneously be a soldier and serve God. To do so, individuals should not by default resort to violence. Only when in defense of oneself or others could violence be acceptable. Indeed, failure to act justly in the face of a grave wrong is sinful. Augustine did not enumerate conditions for the just use of aggression but formulated the term "just war" himself in his City of God: "But, say they, the wise man will wage just wars. As if he would not all the rather lament the necessity of just wars, if he remembers that he is a man; for it they were not just he would not wage them and would therefore be delivered from all wars." ${ }^{5}$ Aquinas built off Augustine's foundation nine centuries later in outlining three conditions for just war. First, a proper authority such as the state, which represents the common good, must wage the war. Second, the war must have a just purpose, not simply for self-gain or exercise of power. And third, peace must be the ultimate goal. These bases formed the framework for the modern conception of just war. ${ }^{6}$

The School of Salamanca and the Catechism of the Catholic Church further elucidated the Augustinian and Thomist constructions. Spanish and Portuguese theologians in the sixteenth century agreed with their predecessors that unless a greater evil threatened, war should be avoided. In all circumstances a treaty or diplomatic agreement is preferable. But, two parties may wage a "just" war where a negotiated settlement is out of reach. The conditions are: in self defense (with a reasonable chance of success), preventive war against imminent attack, and to punish a guilty enemy. But, in counter to Aquinas, observers cannot judge war to be ethically just or unjust solely based on original motive. There are conditions it must meet. These include proportionality, popular support, fair treatment of civilians and hostages, and exhausting all attempts at negotiating a peaceful settlement before war begins. ${ }^{7}$ The Catechism clarified and codified these points in Catholic doctrine:

- the damage inflicted by the aggressor on the nation or community of nations must be lasting, grave, and certain;

- all other means of putting an end to [the possibility of war] must have shown to be impractical or ineffective;

4 Francis X. Clooney, "Pain but Not Harm: Some Classical Resources Toward a Hindu Just War Theory," in Just War in Comparative Perspective, ed. Paul Robinson (Burlington, Vt: Ashgate, 2003), 117-18.

5 St. Augustine of Hippo, The City of God. (New Advent, 2009), http://www.newadvent.org/fathers /120119.htm.

6 See St. Thomas Aquinas, Summa Theologica. (2008), http://www.newadvent.org/summa/3040.htm.

7 Nicholas Rengger, Just War and International Order: The Uncivil Condition in World Politics (Cambridge: Cambridge University Press, 2013), 73-78. 
- there must be serious prospects of success;

- the use of arms must not produce evils and disorders graver than the evil to be eliminated. The power of modern means of destruction weighs very heavily in evaluating this condition. ${ }^{8}$

International law embodies the spirit of just war theory to try to ensure that great power wars occur in accordance with ethical legal principles. Likewise, international institutions such as the United Nations exist to negotiate disputes and mitigate tension between states, invoking the tenets of self-defense, preemptive war, and proportionality.

\section{Jus in Bello, not Jus ad Bellum}

J

ust war theory distinguishes between the conditions necessary for going to war in the first place (jus ad bellum) and the conditions for conducting war (jus in bello). The seven conditions under jus ad bellum are:

\section{Just Cause}

There must be imminent danger, and intervention must be to protect life.

\section{Comparative Justice}

There must be significant disparity between the injustices suffered by one party than the other.

\section{Right Intention}

Force may only be used for the pur- pose of the just cause and no other, such as material gain.

\section{Right Authority}

Only public authorities in a political system that practices the rule of law may wage war.

\section{Probability of Success}

There must be a reasonable chance of success to use force; otherwise, military action is not worth pursuing.

\section{Last Resort}

All viable alternativ to the use of force must be exhausted.

\section{Proportionality}

The expected benefits of military force must be proportional to the expected harms.

Numerous authors have already assessed, or touched upon, the Kosovo intervention from the jus ad bellum perspective, with even fewer from the jus in bello view. Moeller (2000) offered a limited analysis of the case for Kosovo intervention, finding that NATO only met the criteria of just cause and just authority. Prominent just war theorist Orend (1999) came to a different conclusion. He believed that the intervention was indeed just because of Yugoslavian President Slobodan Milosevic's practices of ethnic cleansing against Albanian Kosovars, even despite skepticism regarding pre-war estimations on proportionality. Enuka (2013) revealed

8 Catechism of the Catholic Church, (Washington, D.C.: United States Catholic Conference, 1994), 556. 
serious flaws in NATO's intervention, including the disapproval of the United Nations and violation of Article 6 of the North Atlantic Treaty through armed force against a sovereign, non-NATO nation-state. Beach (2000) delves into the NATO's actions during the war. $\mathrm{He}$ finds fault in discrimination and the use of cluster bombs. And, finally, Elshtain (2001) argues that NATO's opening of sorties gave Milosevic an excuse for declaring martial law. The above authors merely give a passing assessment of the jus in bello violations of the just war theory. This article explores NATO's behavior during the war and weighs it against principles of jus in bello. The criteria used to measure NATO's actions during the intervention are:

\section{Distinction}

Military action should distinguish between enemy combatants and non-combatants. Targeting civilian residential areas that include no military targets and committing acts of terrorism are expressly prohibited. Similarly, combatants must refrain from violence against enemy combatants who have surrendered, been captured, are injured, or are simply not lethally threatening.

\section{Military Necessity}

The conduct of the war must follow the principle of minimum force. To limit unnecessary death and destruction, any action during the war must be for a military objective, intended for the purpose of military defeat of the enemy, and not excessive.

\section{Proportionality}

Even in launching an attack against a military objective, civilian injuries and death must be proportional and clearly not excessive in relation to the expected military advantage.

\section{Fair Treatment}

Prisoners of war and enemy soldiers who surrendered no longer pose a threat and must be treated fairly. Torture or other mistreatment is prohibited.

\section{No Means Malum in Se}

Weapons or other methods of warfare universally considered to be evil are prohibited. These include mass rape, forcing soldiers to fight against their own side, and using weapons whose effects cannot be easily controlled, such as nuclear and chemical weapons.

\section{What Were the Circumstances?}

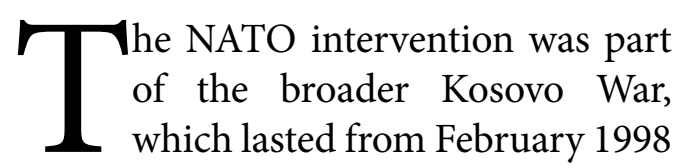
to June 1999. The Federal Republic of Yugoslavia (FRY), a successor state to the Socialist Federal Republic of Yugoslavia that consisted of the Republic of Serbia and the Republic of Montenegro from 1992 to 2003, controlled Kosovo before fighting began. The FRY fought against Kosovo Albanians, many of whom organized under the Kosovo Liberation Army (KLA). A radical group, the KLA was established in 1991 as part of a separatist movement in the south of 
Serbia. It began targeting Serbian police stations in Kosovo in 1995-96 and began acquiring large amounts of arms from Albania, as a result of a rebellion and subsequent looting of army posts. ${ }^{9}$ Attacks against FRY authorities in Kosovo continued through 1998, when Serbian civilian and military forces began retaliating against KLA members and supporters. Retribution killing intensified, leaving nearly 2,000 Kosovars dead and driving hundreds of thousands out of Kosovo. ${ }^{10}$ By March 1999, the US State Department claimed that 500,000 Kosovar Albanians were missing and feared dead. Two months later, US Defense Secretary William Cohen declared, "We've now seen about 100,000 military-aged men missing... They may have been murdered." And, David Scheffer two weeks later made the situation look ever more glum, saying that as many as "225,000 ethnic Albanian men aged between 14 and 59" were missing. Media headlines such as "Flight From Genocide" and "Echoes of the Holocaust" sensationalized the situation. The longer the US and NATO hesitated, the public was led to believe, the more of a chance full-fledged genocide would erupt.

The media and political leaders declared NATO's campaign in Kosovo a humanitarian intervention. Javier Solana, Secretary General of NATO, directed Supreme Allied Commander Europe Wesley Clark to "initiate air operations in the Federal Republic of Yugoslavia" on March 23, 1999. ${ }^{11}$ The next day, the bombing began and lasted until June $11 .{ }^{12}$ Most NATO members played at least minimal roles in the operation, which saw almost 1,000 aircraft running 38,000 combat missions. Aircraft operated from bases in Italy and aircraft carriers in the Adriatic Sea, and Tomahawk cruise missiles were deployed from aircraft, ships, and submarines. NATO's goals in the operation were to expel FRY troops from Kosovo, replace them with international peacekeepers, and allow Albanian refugees to return to their homes. A NATO spokesperson articulated the plan, "Serbs out, peacekeepers in, refugees back." ${ }^{3}$

Strategically, the goal was to destroy FRY air defenses and high-value military targets. Poor weather, and thus visibility, hampered early success. In addition, Milosevic and his forces proved difficult to weaken. Western leaders expected the entire campaign to last no more than a few days, but Milosevic was much more resilient than initially expected. Meanwhile, Milose-

9 Susan Fink Yoshihara, "Kosovo," in Flashpoints in the War on Terrorism, ed. Derek S. Reveron and Jeffrey Stevenson Murer (New York: Routledge, 2006), 68-69.

10 Tim Judah, The Serbs: History, Myth, and the Destruction of Yugoslavia (New Haven: Yale University Press, 2000), 308.

11 Barton Gellman, "NATO Mobilizes for Attack/Yugoslavia Declares State of Emergency," San Francisco Chronicle March 24, 1999; Javier Solana, "Press Statement,"(March 23, 1999), http://www.nato. int/docu/pr/1999/p99-040e.htm.

12 — "Press Statement,"(March 24, 1999), http://www.nato.int/docu/pr/1999/p99-041e.htm.

13 Eric D. Patterson, Ending Wars Well: Order, Justice, and Conciliation in Contemporary Post-Conflict (New Haven: Yale University Press, 2012), 50. 
vic intensified his ethnic cleansing operation, driving hundreds of thousands of Albanian Kosovars from Kosovo. By April 3, UNHCR ${ }^{14}$ officials reported 45,000 Kosovars at the Macedonian border, over half of whom were expelled from Pristina, Kosovo's capital. ${ }^{15}$ Another 25,000 arrived at the Albanian border three days later. Most of the refugees were in poor physical condition. A postwar report issued by the UNHCR concluded that nearly a half million people were expelled from their homes over a two-week period, and the number rose to almost 850,000 in the ensuing weeks. ${ }^{16}$

Aerial bombardment continued as NATO military operations began to attack FRY units on the ground, such as tanks and artillery weapons. But politics in Brussels bogged down this strategy: each of the nineteen member states of NATO needed to approve each military target before engaging. This inefficiency incited British Prime Minister Tony Blair to advocate the use of ground forces, and he pressured other NATO countries, especially the United States, to consider the option. But the United States would be making the largest troop contribution, and President Bill Clinton was reluctant to commit ground troops. ${ }^{17}$
Finnish and Russian diplomatic negotiators meanwhile attempted to persuade Milosevic to back down. When he recognized that Russia, who had voiced strong opposition to the NATO mission, would not intervene to defend Yugoslavia, Milosevic accepted the conditions offered by the mediation team and agreed to a UN-NATO coalition presence in Kosovo. Norwegian special forces worked with the KLA in gathering intelligence information and monitoring events in Kosovo on the ground in the days prior to the arrival of peacekeepers. The Norwegian special forces were among the first to enter Pristina after the peace deal had been brokered. Their job was to establish local relations to implement the deal between the FRY and the Kosovar Albanians. ${ }^{18}$

Slobodan Milosevic agreed to the terms of the peace plan and an end to the fighting on June 3, 1999. The North Atlantic Council ratified the agreement a week later, and the coalition peacekeeping Kosovo Force (KFOR) entered Kosovo. ${ }^{19}$ Although prepared for combat, KFOR only engaged in peacekeeping. A combination of British, French, German, Italian, and American forces composed KFOR at the outset and presided over the peaceful resolution to the

14 United Nations High Commissioner for Refugees

15 Solana, "Press Statement."

16 Astri Suhrke et al., "The Kosovo Refugee Crisis: An Independent Evaluation of UNHCR's Emergency Preparedness and Response," (Geneva: UNHCR, February 2000), 5.

17 Andrew Marr, A History of Modern Britain (London: Macmillan, 2008), 550.

18 Hakon Lunde Saxi, Norwegian and Danish Defence Policy: A Comparative Study of the Post-Cold War Era (Oslo: Norwegian Institute for Defence Studies, 2010), 38.

19 Javier Solana, “Press Statement,"(June 10, 1999), http://www.nato.int/kosovo/press/p990610a.htm. 
three-month bombing campaign. Were NATO tactics and actions necessary and ethical under the tenets of distinction, military necessity, proportionality, fair treatment, and no means malum in se?

\section{Applying the Criteria}

\section{Distinction, Military Necessity, Proportionality}

The most convincing evidence of unjust military force deals with the failure to distinguish between combatants and non-combatants, attacking non-military targets, and using force beyond that which is militarily advantageous. NATO's particular method of warfare made these just war rules difficult with which to comply. Aerial bombardment, rather than the deployment of ground forces, may lend itself to a greater degree of disproportionality in achieving a specific military goal. With this method of intervention, in general, extreme discretion and precaution must be used to avoid civilian casualties. NATO, having employed high-altitude bombing and avoiding ground troop deployment, escaped the conflict without a casualty. This was not the case for Serbian troops on the ground. NATO planes rarely flew below 15,000 feet, the minimum altitude specified by the rules of engagement. Pilots could attack a target only on vi- sual recognition, which did not always mean that the pilot could distinguish between a civilian and military object. Aerial bombardment, while relatively safe for NATO personnel, hampered the precision necessary for waging war within the limits of just war and led to unnecessary civilian casualties. ${ }^{20}$

The first case under contention is the bombing of the Grdelica Gorge passenger train. Supposedly a line in a Yugoslav communications supply network, the Leskovac railway bridge in eastern Serbia was the target of a laser-guided bomb on April 12, 1999. Immediately after launching the bomb, the pilot recognized a passenger train heading toward the bridge. The pilot was unable to dump the bomb via remote direction, and it struck the train on the bridge. Upon seeing that the bridge had not been struck, the pilot launched a second bomb, which also hit the train. The incident resulted in ten civilian deaths and fifteen civilian casualties. ${ }^{21}$ NATO General Wesley Clark and the United States Department of Defense shared regret over the "accident." 22 The pilot claimed he was focused only on the bridge and not the train, which he said had come into his view only after deploying both bombs. The October 2000 Independent International Commission on Kosovo report concluded that the bridge itself was a legitimate

20 David Wippman, "Kosovo and the Limits of International Law," Fordham International Law Journal 25, no. 1 (2001): 146.

21 Elmer Schmahling, "More of Less Exposed Non-Combatants and Civilian Objects under the Conditions of 'Modern Warfare,"' in Mathematics and War, ed. Jens Hoyrup and Bernhelm Booss (Berlin: Birkhauser, 2003), 287.

22 Jamie Shea and Wesley Clark, "Press Conference,"(April 13, 1999), http://www.nato.int/kosovo/ press/p990413a.htm. 
military target but did not determine whether the pilot was reckless in his deployment of the second bomb.

The incident at the Leskovac bridge reveals violations of distinction and proportionality. NATO's method of attack, aerial bombing via remote viewing on a screen in the pilot's seat, made verifying that the target had not been compromised by the presence of civilians difficult. Provided that the bridge was a preapproved military target, the method violates simple laws of armed conflict. If the pilot was unable to distinguish between the military target and any civilians that could have been in the area, then aerial bombing should not have been used. But, if he could distinguish, then the pilot could have performed a precautionary flyover or a prior review of train timetables and movements. In addition, NATO forces could have forewarned the FRY public of military targets to prevent civilian casualties. There was no evidence that the pilot or NATO took these measures, violating NATO's obligations to take all reasonable precautions to prevent loss of civilian casualties. ${ }^{23}$

The deployment of the second bomb is more troublesome. Whereas the pilot deployed the first bomb without knowing of civilian presence in the area, he dropped the second knowing that the train was on the bridge and traveling in the direction of the target location. Even if smoke concealed the bridge, the pilot should have taken additional precautions to spare civilian lives at all costs. And, if the mission was to destroy the bridge no matter the cost, then the case causes additional concern for the rules of discrimination and proportionality. NATO never revealed any substantial military advantage from the destruction of the bridge in relation to the potential cost to civilians. And, the pilot failed to suspend the attack once the presence of defenseless civilians became apparent, violating Article 57 (2) of the Geneva Convention Additional Protocol I, which says (state and cite). The bombing of the Grdelica Gorge passenger train thus violates the rules of distinction and proportionality. ${ }^{24}$

The second case involves the bombing of an Albanian refugee convoy on Djakovica-Prizren road two days after the Grdelica incident. The Yugoslav Army and Special Police Forces used this route for supplying and reinforcing troops, and there were claims of ethnic cleansing in the area. The sight of burning villages informed NATO forces that the Yugoslav Army and Special Police Forces were operating there, pushing Kosovars out. At around 10:30 AM, dark green vehicles, assumed to be carrying troops, were seen near one of the newly lit houses. Two F-16 jets bombed the vehicles, starting with the

23 ICTY, "Final Report to the Prosecutor by the Committee Established to Review the NATO Bombing Campaign against the Federal Republic of Yugoslavia," (The Hague: United Nations International Criminal Tribunal for the former Yugoslavia, June 13, 2000), 22.

24 Timothy L.H. McCormack and Helen Durham," Aerial Bombardment of Civilians: The Current International Legal Framework," in Bombing Civilians: A Twentieth-Century History, ed. Yuki Tanaka (New York: The New Press, 2010), 233. 
lead vehicle. A third plane attacked another nearby convoy, claiming it to be an army guard. The assault continued for another two and a half hours until it was called off to review the strikes. NATO bombs killed between seventy and seventy-five Albanian refugees and injured nearly a hundred. ${ }^{25}$

To avoid Yugoslav anti-aircraft fire, the NATO planes on this day flew higher than 15,000 feet. Sighting their targets with the naked eye instead of remote video technology, the pilots assumed the convoys they saw were military vehicles because of their movement, size, shape, color, and speed. Cockpit video, however, shows that they were tractors. Even though there were claims that Yugoslav forces were operating civilian vehicles, NATO changed its rules of engagement to prohibit attacks on military-use civilian vehicles. This precaution conveys how NATO took necessary steps to prevent civilian death. ${ }^{26}$

The fault does not lie in the altitude at which the planes were flying. Rather, pilots operating at high altitude and high speed would struggle to distinguish between a military and a civilian vehicle. While flying at a lower altitude may have made NATO aircraft susceptible to Yugoslav air defense systems, the higher altitude made distinction unlikely. Bombing without certainty does not meet the burden of proof for justifiable bombing. Only by flying lower and with clear visibility for distinction would bombing be acceptable. NATO would have had to decide whether the importance of destroying the target outweighed the potential danger to its aircraft. To fly at higher altitudes without the ability to verify bombing objectives and take necessary precautions to protect civilian life proves unjust and is a violation of the rule of distinction. ${ }^{27}$

The third case is the intentional bombing of the Serbian Radio and Television Station on the night of April 23, 1999. Estimated civilian deaths range between ten and seventeen. The Federal Republic of Yugoslavia used the station for military purposes, and, because of its role in in the command, control, and communications network in the country, NATO targeted it. NATO also justified the bombing, arguing that Yugoslav President Slobodan Milosevic used the station as a war propaganda outlet. ${ }^{28}$ NATO considered the station as legitimate target, since it sought to disrupt the communications system of the FRY army. ${ }^{29}$ But the station itself was a civilian object. Rather than attacking urban studios, where civilians worked, pilots

25 Andrew J. Bacevich and Elliot A. Cohen, War over Kosovo: Politics and Strategy in a Global Age (New York: Columbia University Press, 2001), 15.

26 Human Rights Watch, “The Crisis in Kosovo," (February 2000), http://www.hrw.org/reports/2000/ nato/Natbm200-01.htm.

27 Ibid.

28 Hans-Peter Gasser, “The Journalist's Right to Information in Time of War and on Dangerous Missions," in Yearbook of International Humanitarian Law - 2003, ed. Timothy McCormack and Avril McDonald (New York: Springer, 2003), 381.

29 McCormack and Durham," Aerial Bombardment of Civilians: The Current International Legal 
could have targeted electronic transmitters to disrupt the Yugoslav communication network. A list compiled by the International Committee of the Red Cross included broadcasting and television installations as of primary military importance. ${ }^{30}$ By themselves, radio and television stations are not military targets. But, if the Serbian station truly contributed to military action, communication, and distribution, then its partial destruction or neutralization provided military advantage as required in the rule of military necessity. But NATO additionally justified the attack because of Milosevic's propaganda dissemination at the station, which does not adequately justify military action unless the propaganda incited violence. The UN Final Report on the NATO bombing campaign noted,

While stopping such propaganda may serve to demoralize the Yugoslav population and undermine the government's political support, it is unlikely that either of these purposes would offer the "concrete and direct" military advantage necessary to make them a legitimate military objective. NATO believed that Yugoslav broadcast facilities were "used entirely to incite hatred and propaganda" and alleged that the Yugoslav government had put all private $\mathrm{TV}$ and radio stations in Serbia under military control (NATO press conferences of 28 and 30 April1999). However, it was not claimed that they were being used to incite violence akin to Radio Milles Collines during the Rwandan genocide, which might have justified their destruction. ${ }^{31}$

If the station engaged in military communications, and thus proved to be a legitimate military objective, the bombing still violated the rules of proportionality. As NATO predicted, the bombing only took communications off the air for a few hours. The attack was part of a larger strategy to destroy the Yugoslav command and control network, rather than an isolated incident. Thus, international observers presumed the bombing to be an appropriate attack. But that the broadcasting station was up and running within a few hours indicates the relative impermanence of the station's destruction in the overall strategy. It is doubtful that NATO gained significant military advantage in this short amount time that was proportional to the deaths of up to seventeen civilians. ${ }^{32}$ It should be noted as well that the FRY should be faulted for placing civilians in harm's way.

Advanced warnings could have been given in this instance, and there

Framework," 235.

30 ICTY, "Final Report to the Prosecutor by the Committee Established to Review the NATO Bombing Campaign against the Federal Republic of Yugoslavia."

31 Ibid.

32 "NATO Challenged over Belgrade Bombing," BBC News (October 24, 2001), http://news.bbc. co.uk/2/hi/europe/1616461.stm. 
are disputes over the extent to which FRY knew that the station was in danger of targeting. NATO reported that it had not issued a warning so as to protect pilots in the area from anti-aircraft fire. Western journalists, however, insist that a CNN contact warned them to stay clear from the station. It seems that NATO hinted to its own personnel as well as media contacts that the station was being targeted but failed to warn Yugoslav civilians and management of the station of the impending attack. The efficacy of the station bombing to the overall strategy of cutting communication lines and the mixed accounts on effectively forewarning civilians breaches the rule of proportionality under just war theory. ${ }^{33}$

The bombing of the Chinese Embassy in Belgrade on May 7, 1999 is the fourth case. Several NATO missiles struck the embassy, causing extensive damage to it and surrounding buildings and killing three Chinese citizens and wounding about fifteen others. The United States government in conjunction with NATO admitted that the bombing was a mistake and that the actual target was the Yugoslav Federal Directorate for Supply and Procurement, which NATO considered a legitimate military target. The confusion over identifying the correct target stemmed from land navigation techniques and faulty military and intelligence databases, both of which failed to provide accurate target information. According to the UN Final Report, "[NATO] used techniques known as 'intersection' and 'resection' which, while appropriate to locate distant or inaccessible points or objects, are inappropriate for use in aerial targeting as they provide only an approximate location." ${ }^{34}$ Allegedly, mid-level intelligence officers suspected that these techniques misidentified the target, yet the officers failed to relay this information to senior managers who may have been able to call off the attack. ${ }^{35}$ The Chinese government and many of its citizens were outraged by the bombing, holding protests in Beijing for retribution. NATO and President Clinton responded with a formal apology and a compensation payment of $\$ 28$ million to the Chinese government and $\$ 4.5$ million to the families of the dead and injured. The United States government also ensured that it took disciplinary and corrective actions to avoid these incidents in the future. ${ }^{36}$

There is no doubt that the Chinese Embassy was clearly a civilian rather than a military target. Neither aircrew nor senior military commanders were aware of the faulty information, so blame does not fall on their shoulders. Ultimately, whether the attack on the embassy was deliberate may never be

33 Gasser, "The Journalist's Right to Information in Time of War and on Dangerous Missions," 381.

34 ICTY, "Final Report."

35 Craig R. Whitney, “U.S. Military Acted Outside Nato Framework During Kosovo Conflict, France Says," New York Times November 11, 1999.

36 Kerry Dumbaugh, “Chinese Embassy Bombing in Belgrade: Compensation Issues," (Congressional Research Service, April 12, 2000). 
known. Clearly, if the attack was deliberate, the rules of distinction, military necessity, and proportionality, as well as broader laws of armed conflict, would be violated. Even if the attack proved to be a mistake, NATO failed to take adequate precautions to ensure the validity of its target information. Verification of the location of the target on the ground and ensuring the accuracy of the databases and maps used are relatively simple tasks, which NATO personnel seemingly did not perform. ${ }^{37}$ Even more distressing is that NATO continued its bombing campaign using the same inaccurate maps and databases instead of temporarily halting the attacks until the problem could be rectified. ${ }^{38}$ Proportionality seemed to be an afterthought rather than a precaution in the embassy attack.

The final case is the attack on the village of Korisa on May 14, 1999, which killed eighty-seven civilians, mostly refugees, and injured sixty others. NATO dropped ten bombs intended for a nearby Serbian military camp and command post. The attack occurred at night, which obscured visibility. General Walter Jertz, speaking on behalf of NATO, explained,

the pilot...had to visually ident- ify [the target].... and you know it was by night, so he did see silhouettes of vehicles on the ground and as it was by prior intelligence a valid target, he did do the attack... So for the pilot flying the attack, it was a legitimate target... Of course, and we have to be very fair, we are talking at night. If there is anybody sleeping somewhere in a house, you would not be able to see it from the perspective of a pilot. But, once again, don't misinterpret it. It was a military target which had been used since the beginning of conflict over there and we have all sources used to identify this target in order to make sure that this target was still a valid target when it was attacked. ${ }^{39}$

NATO took all practical precautions to determine the presence or absence of civilians, given the darkness of night. NATO officials believed that civilians were not in the area, and the goal was to attack a legitimate military target.

Some evidence suggests that FRY forces had coerced Kosovar civilians into serving as human shields, placing the blame instead on the FRY military

37 John Sweeney and Ed Vulliamy argued that NATO deliberately targeted the Chinese embassy, arguing that NATO detected communication signals from the embassy to FRY forces. See John Sweeney and Ed Vulliamy, "NATO Bombed Chinese Deliberately," New York Times (October 16, 1999), https://www.theguardian.com/world/1999/oct/17/balkans.

38 "Collateral Damage' or Unlawful Killings?: Violations of the Laws of War by NATO During Operation Allied Force," (Amnesty International, 2000), 53-54.

39 "ICTY, Final Report to the Prosecutor by the Committee Established to Review the NATO Bombing Campaign against the FRY, Pr/P.I.S./510-E, 13 June 2000," in The Kosovo Conflict and International Law: An Analytical Documentation, 1974-1999, ed. Heike Krieger (Cambridge: Cambridge University Press, 2001), 352. 
forces. ${ }^{40}$ Nevertheless, civilians died, and NATO was bound by Article 51 (8) of the Additional Protocol I to abide by the rule of distinction in all cases, no matter the reason civilians may be in the area. That Kosovars may have been used as human shields is no excuse under Article 51 (8). ${ }^{41}$ NATO repeatedly passed off responsibility because of nighttime darkness, which indicates NATO lowered its standards of distinction. There was no evidence that flying at night was of military necessity. But, NATO, with full knowledge that identifying and distinguishing targets at night would pose difficulties, made the decision for night flying anyway. NATO identified silhouettes of vehicles on the ground and presumed that they were similar to those military objects from prior intelligence reports. But this assumption falls short of the requirement of taking all precautions to prevent loss of civilian life. It is unclear whether FRY forces or military objectives were even present in Korisa at the time of the bombing. Even if the target had been a military installation, NATO failed to take the adequate precautions necessary to account for civilians in the vicinity in accordance with Article 57 (2) of the Additional Protocol I, to "do everything feasible to verify that the objectives to be attacked are neither civilians nor civilian objects" and "refrain from deciding to launch any attack which may be expected to cause incidental loss of civilian life, injury to civilians, damage to civilian objects, or a combination thereof, which would be excessive in relation to the concrete and direct military advantage anticipated. ${ }^{42}$ Distinction between civilian and military personnel was lost in the darkness at Korisa. ${ }^{43}$

In the eleven-week period of the intervention, NATO used over 15,000 bombs and munitions in its air campaign, about 13,000 tons of explosive power. Estimated civilian deaths range between 1,200 and 2,000, one for every ten tons of explosives detonated. These staggering numbers compare with major bombing campaigns during the Vietnam War, such as the Christmas 1972 bombing around Hanoi and Haiphong Harbor where 20,000 tons of explosives killed 1,600 civilians. ${ }^{44}$

Even after the ceasefire, NATO still ran into problems of distinction. Undetonated cluster bombs were still producing deaths and casualties months after the end of the Kosovo War. Both the United States and Great Britain acknowledged the use of cluster bombs in the intervention. The Interna-

40 Ian Fisher, "Crisis in the Balkans: Refugees; They Were Human Shields When 80 Died, Kosovars Say," New York Times May 31, 1999.

41 This point does not absolve the FRY military for using human shields, which is a war crime by itself.

42 International Committee of the Red Cross, "Protocols to the Geneva Conventions of 12 August 1949," (May 2010).

43 "ICTY, Final Report to the Prosecutor by the Committee Established to Review the NATO Bombing Campaign against the FRY, Pr/P.I.S./510-E, 13 June 2000,” 352.

44 Christopher Layne, "Collateral Damage in Yugoslavia," in NATO’s Empty Victory: A Postmortem on the Balkan War, ed. Ted Galen Carpenter (Washington, D.C.: Cato Institute, 2000), 54. 
tional Campaign to Ban Landmines reported, "[T]he U.S. dropped 1,000 cluster bombs of the type CBU-87/B, each containing 202 BLU-97/B bomblets and the UK dropped 500 RBL/755 cluster bombs, each containing 147 Bl-755 bomblets." These submunitions within the cluster bombs had a failure rate of about five percent, rendering the bomblets de facto landmines. ${ }^{45}$ Between June 13 and July 12, 1999, between 130 and 170 civilians were injured or killed in unexploded cluster bomb accidents, according to the World Health Organization. The Mine Action Coordination Center in Pristina disclosed that this rate of about 10 per 100,000 is "comparable to that previously experienced in other emergency situations such as Afghanistan and Cambodia." 46 The high casualty rate is partly a result of the downplaying of the danger. Phil Straw of the HALO Trust, a group of former British Army engineers and explosives experts, remarked, "The mine problem is much higher than....anticipated, far higher." ${ }^{47}$ In the months after the war, about 400,000 cluster bombs were spread over uninhabited areas near the southern borders of Yugoslavia, but there were thousands in Kosovo. Inanimate explosives do not distinguish between civilian and combatant.

These five cases and the postwar mine problem point to violations of just war rules of distinction, military necessity, and proportionality and provide the most convincing evidence of unjust military force against Yugoslav and Albanian civilians.

\section{Fair Treatment}

Because of the nature of air war, combatants do not often meet face to face. This was at least the case for NATO coming into contact with Yugoslav combatants. NATO, however, directly supported the Kosovo Liberation Army, which allegedly engaged in the torture of Serbs and Roma. ${ }^{48}$ The BBC detailed in April 2009 a secret KLA network of prisons used to carry out torture and murders during and after the NATO intervention. ${ }^{49}$ Reporter Michael Montgomery revealed in "Crossing Continents" news of thousands of missing ethnic Albanians, Kosovo Serbs, and Roma gypsy civilians. One alleged prisoner of the KLA revealed, "I've seen a lot, people beaten, stabbed, hit with steel pipes, left without eating for five or six days. People had bullet proof vests on and were shot to see if it was working, thrown into tombs, beaten up, and killed." Eight former KLA soldiers admitted that they were appalled by the atrocities that occurred, while others saw the vicious acts simply as retribution. One of the soldiers remembered hiding captured Serbs and Roma civil-

45 Under Orders: War Crimes in Kosovo, (New York: Human Rights Watch, 2001), 154.

46 Carlotta Gall, "Mines and NATO Bombs Still Killing in Kosovo, New York Times August 6, 1999.

47 Ibid.

48 Altin Raxhimi, Michael Montgomery, and Vladimir Karaj, "KLA Ran Torture Camps in Albania," Balkan Insight(2009), http://old.balkaninsight.com/en/main/investigations/18064/?tpl=297.

49 Michael Montgomery, "Horrors of KLA Prison Camps Revealed," BBC News April 10, 2009. 
ians as NATO troops passed by, taking them across the border to Albania to be killed. He reflected, "Now, looking back, I know that some of the things that were done to innocent civilians were wrong. But the people who did these things act as if nothing happened, and continue to hurt their own people, Albanians." Another soldier confessed he drove trucks full of Serbian civilian prisoners to Albania to be tortured and killed. "I was sick," he said. "I thought we were fighting a war...but this was something completely different." 50

Some of these crimes occurred in an abandoned factory in the Albanian towns of Kukes and Burrel, both of which were KLA military strongholds. The International Centre for the Red Cross first heard of allegations of atrocities occurring in Burrel in 2000, when KLA members leaked a story telling of Serb civilians being taken there in 1999 , having their organs removed and sold abroad. Following the war, the International Criminal Tribunal for the former Yugoslavia (ICTY) and the United Nations Mission in Kosovo (UNMIK) investigated claims of human rights abuses, stumbling upon syringes, empty bottles of relaxant drugs, drip bags, and other surgical equipment, all scattered about on a blood-stained floor. ${ }^{51}$

In Kukes, prisoners were housed in detention centers. Jose Pablo Baraybar of UNMIK's Office for Missing Per- sons and Forensics admitted, "There were people that are certainly alive that were in Kukes, in that camp, as prisoners. Those people saw other people there, both Albanians and non-Albanians. There were members of the KLA leadership going through the camp. Many names were mentioned, and I would say that that is an established fact." 52 UNMIK had knowledge of the KLA's detention centers, but, suspiciously, no investigation followed. Amnesty International Spokesperson Sian Jones accused NATO of neglecting the security of civilians after the war, and said, "the international community was sent in with responsibility for providing a safe and secure environment in Kosovo and these acts happened right under their noses... it was a massive failure to protect minority communities from human rights abuses when that international community was supposed to protect them." ${ }^{3}$ These testimonies of human rights abuses seem much more than hearsay. Indeed, the CIA and U.S. Special Forces worked indirectly with the KLA, using the Albanian $2^{\text {nd }}$ Army as a broker between the two sides. Dana Priest at the Washington Post reported, "U.S. Army Special Forces troops in Kukes and Durres were helping the disjointed, ill-equipped rebels to pass on useful information about Serbian positions." ${ }^{54}$ Blame for these atrocities, then, falls directly on the KLA and at

50 Ibid.

51 Raxhimi, Montgomery, and Karaj, "KLA Ran Torture Camps in Albania."

52 Montgomery, "Horrors of KLA Prison Camps Revealed."

53 Ibid.

54 Dana Priest, "Kosovo Land Threat May Have Won War," Washington Post September 19, 1999, 
least indirectly on NATO, thus violating the rule of fair treatment of civilians and prisoners of war.

\section{No Means Malum In Se}

NATO used depleted uranium (DU) in its munitions. This action possibly violates the principle of no means malum in se, because the long-term effects of its use cannot be easily controlled. When DU munitions contact the target, uranium metal partially burns, creating uranium oxide. Wind can then spread the chemical great distances, making the side effects of using DU uncontrollable. Accordingly, Geneva Additional Protocol I 51(4) prohibits indiscriminate harm, but does not specifically comment on DU. ${ }^{55}$ Used to make anti-tank shells more deadly and tank armor more rigid, DU is believed to have caused the cancer deaths of nearly thirty former Balkan peacekeepers. These critics point to the 1991 Gulf War, when reports revealed that hundreds of American soldiers suffered DU poisoning, and the high cancer rates of southern Iraqis, who had been exposed to DU shells. Like Iraq, the Kosovo intervention saw widespread DU use. NATO warplanes, including American A-10 "Warthogs," fired $30 \mathrm{~mm}$ bullets with DU cores. About 30,000 rounds of these DU munitions were deployed in the ten-week campaign. ${ }^{56}$
The presence of DU in bullets and armor used in the war is linked to a high prevalence of leukemia in southern Serbia, Kosovo, and Albania, while the long-term environmental effects are yet to appear. Others, such as Lt. Col. Alexander Willing, a KFOR spokesman rejected these claims, saying, "NATO's use of DU in the Kosovo conflict did not cause any continuing health risk and therefore no further action was required on our part." ${ }^{57}$ The United Nations sent a team to a few of the sites where NATO found DU munitions in 2000 , subsequently issuing a report that also denied contamination of soil and water. But this report is unable to account for longer term dangers. The precautionary principle and the principle of intergenerational equity in environmental law can apply to DU in the absence of scientific certainty on long term health and environmental effects. NATO is responsible for using potentially toxic weapons that could harm future generations. ${ }^{58}$ Also, DU bullets are known to penetrate as far down as seven meters, much deeper than some shallow groundwater wells. When uranium comes into contact with water and oxygen, it rusts quickly and can easily contaminate water sources.

Despite competing claims, locals continue to blame the DU munitions (for...). One Kosovo citizen attested,

https://www.washingtonpost.com/wp-srv/national/daily/sept99/airwar19.htm.

55 Nikhil Shah, "Depleted Uranium and International Law," Counter Currents October 23, 2004, https://countercurrents.org/du-shah231004.htm.

56 Nate Tabak, “Uranium Risks Haunt Kosovo Survivors," Deutsche Welle (November 13, 2012), http:// www.dw.de/uranium-risks-haunt-kosovo-survivors/a-16366645-0

57 Ibid.

58 Shah, "Depleted Uranium and International Law." 
"There are many cases of leukemia and so on... A lot of people are getting sick. I think it's a combination of factors. People are traumatized by the war, but it's also caused by the weapons used." 59 Likewise, Kosovo and Serbia media reports confirm higher rates of leukemia in areas of DU use. But, authorities, especially Kosovo's Institute of Public Health, have yet to extensively study the issue, citing the lack of reliable data. The World Health Organization does maintain its concern for possible hazardous environmental effects to come and advocates continued monitoring.

The use of DU in general is controversial and has legal ambiguity. Y.K.J. Yeung Silk Yuen presented "Legal Compliance of Weapons Containing DU as a New Weapon" in 2002 to the United Nations Sub-Commission on the Promotion and Protection of Human Rights. In the report, he contended that the use of DU weapons may be in violation of the Universal Declaration of Human Rights, the Genocide Convention, the United Nations Convention Against Torture, the Geneva Conventions, including Protocol I, the Convention on Conventional Weapons of 1980, the Chemical Weapons Convention, and the Charter of the United Nations. He argued,

Annex II to the Convention on the Physical Protection of Nuclear Material 1980 (which became operative on 8 February
1997) classifies DU as a category II nuclear material. Storage and transport rules are set down for that category which indicates that DU is considered sufficiently "hot" and dangerous to warrant these protections. But since weapons containing DU are relatively new weapons no treaty exists yet to regulate, limit or prohibit its use. The legality of illegality of DU weapons must therefore be tested by recourse to the general rules governing the use of weapons under humanitarian and human rights law... [P]arties to Protocol I to the Geneva Conventions of 1949 have an obligation to ascertain that new weapons do not violate the laws and customs of war or any other international law. As mentioned, the International Court of Justice considers this rule binding customary humanitarian law. ${ }^{60}$

While Yuen dictates that the use of DU must meet the burden of proof of clear legality, Louise Arbour, chief prosecutor for the ICTY is doubtful that a DU consensus is forthcoming:

There is no specific treaty ban on the use of DU projectiles. There is a developing scientific debate and concern expressed regarding the impact of the use of such projectiles and it is possible that,

59 Ibid.

60 Y.K.J. Yeung Sik Yuen, "Human Rights and Weapons of Mass Destruction, or with Indiscriminate Effect, or of a Nature to Cause Superfluous Injury or Unnecessary Suffering," (United Nations, Commission on Human Rights, June 27, 2002), Para. 133. 
in the future, there will be a consensus view in international legal circles that use of such projectiles violate general principles of the law applicable to the use of weapons in armed conflict. No such consensus exists at present. ${ }^{61}$

Currently, DU falls into a gray area in international law, where no agreement explicitly bans its use. Instead, to employ or not employ DU weapons is left to ethical conscience and better judgment.

With the ambiguity of international law in mind, the only determination for the ethics of DU use is the environmental and health effects it has on the region in which it is employed. If there is a causal link between depleted uranium and cancer, then NATO should be held accountable for the use of the material. If the link tenuous, however, NATO's use of the controversial munitions should still be in question because of the humanitarian rhetoric that the US used to justify the intervention. Why would potentially disastrous weapons be used in a campaign intended to prevent such humanitarian disasters? International law vagueness aside, NATO, in presenting itself as an ethical intermediary, did not place itself in an innocent position by using depleted uranium in its weapons and armor. Therefore, NATO at least partially vio- lated the final rule of no means malum in se, since no clear framework guides the use of depleted uranium.

\section{Discussion and Conclusion}

he discussion over the ethics
of NATO intervention is not to
dismiss the heinous acts and war crimes committed by FRY forces. Clearly, the FRY and the KLA engaged in human rights abuses. But, the focus on NATO is important because of the rhetoric of humanitarian interventionism to prevent ethnic cleansing used to gain support for the campaign. The initial claims of impending genocide seem to contradict the actual conditions on the ground. The Wall Street Journal's own investigation rejected the "massgrave" thesis and showed that the killing fields the western media had been reporting were actually a series of "scattered killings" in KLA territory. Further, it claimed that "NATO stepped up its claims about Serb "killing fields" when it "saw a fatigued press corps drifting toward the contrarian story: civilians killed by NATO's bombs." ${ }^{2}$ The Journal also concluded that the KLA was involved in this propaganda dissemination and that some of the most heinous atrocities reported were simply not true. Agence France-Prasse reported that claims of Milosevic's crimes were often "confused, contradictory, and

61 Joe Sills et al., "Environmental Crimes in Military Crimes in Military Actions and the International Criminal Court - United Nations Perspectives," (Army Environmental Policy institute, April 2001), 28.

62 Daniel Pearl and Robert Block, "Despite Tales, the War in Kosovo Was Savage, but Wasn't Genocide," Wall Street Journal (December 31, 1999), http://online.wsj.com/article/SB946593838546941319. djm.html. 
sometimes wrong." ${ }^{33}$ While the Kosovo War involved "cruel, bitter, [and] savage" behavior, the genocide that media outlets reported was not there. ${ }^{64}$

Violence escalated as soon as NATO bombing began, contradicting the very purpose of the campaign. While British defense secretary George Robertson claimed that NATO intervened "to prevent a humanitarian catastrophe," the Organisation for Security and Co-operation in Europe issued a report confirming the Wall Street Journal's investigation, claiming that most of the crimes against the Albanian population occurred after the intervention began. ${ }^{65}$ Thus, an escalation of killings was not a cause but a consequence of NATO's bombing campaign. ${ }^{66}$ In 1998, before NATO got involved, fighting cost the lives of 1,000 to 2,000 on both sides. In the nearly three months of NATO intervention, the figures rose to many times this number. With the air bombardment came the expulsion of 850,000 Albanians from Kosovo, killings and atrocities against portions of the Albanian population, and some destruction of Albanian property by Yugoslav forces. This is not to suggest that NATO was directly responsible for these atrocities.
But the bombing campaign created a fertile setting for violence to escalate. ${ }^{67}$ As Christopher Layne reported, the Clinton foreign policy team was explicitly warned by both the Pentagon and the U.S. intelligence community that (1) Belgrade would respond to NATO air strikes by undertaking a forcible mass expulsion of Kosovo's ethnic Albanians and (2) the bombing campaign would not be able to stop the Yugoslav army from driving ethnic Albanians out of Kosovo. The event that opened the door for the Yugoslav forces to move from counterinsurgency to population expulsion was the withdrawal of the monitors who had been deployed in Kosovo as part of the October 1998 ceasefire. As one monitor said just prior to the withdrawal order: 'There is a lot of tension in the area. But while they [the monitors] stay where they are, things are more or less O.K.' The monitors were withdrawn on March 19 , to ensure that they would be out of harm's way when the bombing campaign began. The

63 James George Jatras, "NATO’s Myths and Bogus Justification for Intervention," in NATO’s Empty Victory: A Postmortem on the Balkan War, ed. Ted Galen Carpenter (Washington, D.C.: Cato Institute, 2000), 24.

64 Pearl and Block, "Despite Tales, the War in Kosovo Was Savage, but Wasn't Genocide."

65 John Pilger, The New Rulers of the World (London: Verso, 2002), 145, __ , "US and British Officials Told Us That at Least 100,000 Were Murdered in Kosovo. A Year Later, Fewer Than 3,000 Bodies Have Been Found," New Statesman (September 4, 2000), http://www.newstatesman.com/ node/138456.

66 Layne, "Collateral Damage in Yugoslavia," 52-53.

67 Peter Gowan, “The War and Its Aftermath," in Degraded Capability: The Media and the Kosovo Crisis, ed. Philip Hammond and Edward S. Herman (Sterling: Pluto Press, 2000), 43. 
administration was told by the intelligence community, and by its own diplomatic representative in Kosovo, William Walker, that withdrawal of the monitors would be taken by Belgrade as a green light to proceed to drive ethnic Albanians out of Kosovo. ${ }^{68}$

At first, NATO bombing focused on military targets. As the campaign continued, the bombing in Kosovo became increasingly ineffective. In response, air strikes increasingly focused on infrastructure objectives, such as Serbian economic and civil targets. ${ }^{69}$ NATO planes caused massive economic damage in Serbia, hitting 144 civil objectives, including major industrial plants, television stations, and radio networks. In addition, thirty-three medical clinics or hospitals and 344 schools were bombed. The twelve-day raid on the Pacevo petrochemical plant caused widespread pollution, ten thousand times the permitted safety levels in the area. Together, for every five targets hit, three were civilian. Yugoslavia suffered a forty-four percent decline in industrial output and forty percent loss of total production. These findings are additional to the just war violations listed above. ${ }^{70}$

Among the five rules of just war jus in bello, NATO clearly violated the first three: discrimination, military necessity, and proportionality in the cases explored above. the Grdelica Gorge,
Djakovica-Prizren road, Serbian Radio and Television Station, Chinese Embassy, and Korisa village, NATO failed to take the appropriate precautions to avoid unnecessary civilian deaths and casualties, making the entire campaign unhumanitarian in the just war paradigm. These cases show evidence of illegitimate military targets and disproportionate civilian attacks, given the presumed military gain. Regarding the conditions of fair treatment and no means malum in se, the verdict is still out. The KLA, supported by NATO, allegedly operated a network of prison camps and torture facilities. Guilt falls on NATO only if these allegations prove true. Likewise, NATO's use of depleted uranium in its ammunition and armor is in ethical question. Blame depends on the negative effects that it still may have on the population in the area in which NATO left DU fragments. But the evidence shows that NATO violated at least three rules of just war.

That western governments and the media alike proclaimed the ethical duty of NATO to come to Kosovo's rescue reflects an ethical standard that the intervention did not uphold. Its quest to prevent a humanitarian disaster proved only to exacerbate the ongoing violence. Given the rhetoric projected to the world audience, NATO presented itself to uphold humanitarian and ethical norms, including the criteria of just war theory. The truth is still unraveling about ethical violations on each side,

68 Layne, "Collateral Damage in Yugoslavia," 52.

69 Jatras, "NATO’s Myths and Bogus Justification for Intervention," 25.

70 Gowan, "The War and Its Aftermath," 44. 
but the burden of justice falls on the shoulders of the North Atlantic Treaty Organization, which acted on ethical grounds. Just war theory may be a strict doctrine, but in terms of NATO's air campaign in the Balkans in 1999, the very intervention that many claim to be the paragon for all humanitarian wars falls short of just that.

Scott Duryea is Associate Professor of Security and Global Studies at American Public University System. He holds a PhD in International Studies and an MA in American History. His research interests are broad and generally include IR and classical liberal theory, globalization, American interventionism, and themes focusing on individual rights.

\section{Bibliography}

Aquinas, St. Thomas. Summa Theologica. 2008, http://www.newadvent.org/summa /3040.htm.

Bacevich, Andrew J., and Elliot A. Cohen. War over Kosovo: Politics and Strategy in a Global Age. New York: Columbia University Press, 2001.

Blair, Tony. "Blair: 'We Must Act - to Save Thousands of Innocent Men, Women and Children." The Guardian, March 23, 1999.

Catechism of the Catholic Church. Washington, D.C.: United States Catholic Conference, 1994.

Clinton, Bill. "Statement on Kosovo." Miller Center, University of Virginia (March 24, 1999), http://millercenter.org/president/speeches/detail/3932.

Clooney, Francis X. "Pain but Not Harm: Some Classical Resources toward a Hindu Just War Theory." In Just War in Comparative Perspective, edited by Paul Robinson. Burlington, Vt: Ashgate, 2003.

"Collateral Damage' or Unlawful Killings?: Violations of the Laws of War by NATO During Operation Allied Force." Amnesty International, 2000.

Dumbaugh, Kerry. "Chinese Embassy Bombing in Belgrade: Compensation Issues." Congressional Research Service, April 12, 2000. 
Fisher, Ian. "Crisis in the Balkans: Refugees; They Were Human Shields When 80 Died, Kosovars Say." New York Times, May 31, 1999.

Gall, Carlotta. "Mines and NATO Bombs Still Killing in Kosovo." New York Times, August 6, 1999.

Gasser, Hans-Peter. “The Journalist's Right to Information in Time of War and on Dangerous Missions." In Yearbook of International Humanitarian Law - 2003, edited by Timothy McCormack and Avril McDonald. New York: Springer, 2003.

Gellman, Barton. "NATO Mobilizes for Attack/Yugoslavia Declares State of Emergency." San Francisco Chronicle, March 24, 1999.

Gowan, Peter. "The War and Its Aftermath." In Degraded Capability: The Media and the Kosovo Crisis, edited by Philip Hammond and Edward S. Herman. Sterling: Pluto Press, 2000.

Hippo, St. Augustine Of. The City of God. New Advent, 2009, http://www.newad vent.org/fathers/120119.htm.

Holzgrefe, J.L., and Robert O. Keohane, eds. Humanitarian Intervention: Ethical, Legal and Political Dilemmas. Cambridge: Cambridge University Press, 2003.

Human Rights Watch. “The Crisis in Kosovo." (February 2000), http://www.hrw. org/reports/2000/nato/Natbm200-01.htm.

ICTY. "Final Report to the Prosecutor by the Committee Established to Review the Nato Bombing Campaign against the Federal Republic of Yugoslavia." The Hague: United Nations International Criminal Tribunal for the former Yugoslavia, June 13, 2000.

"ICTY, Final Report to the Prosecutor by the Committee Established to Review the NATO Bombing Campaign against the Fry, Pr/P.I.S./510-E, 13 June 2000." In The Kosovo Conflict and International Law: An Analytical Documentation, 19741999, edited by Heike Krieger. Cambridge: Cambridge University Press, 2001.

Jatras, James George. "NATO’s Myths and Bogus Justification for Intervention." In NATO's Empty Victory: A Postmortem on the Balkan War, edited by Ted Galen Carpenter. Washington, D.C.: Cato Institute, 2000.

Judah, Tim. The Serbs: History, Myth, and the Destruction of Yugoslavia. New Haven: Yale University Press, 2000. 
Layne, Christopher. "Collateral Damage in Yugoslavia." In NATO's Empty Victory: A Postmortem on the Balkan War, edited by Ted Galen Carpenter. Washington, D.C.: Cato Institute, 2000.

Marr, Andrew. A History of Modern Britain. London: Macmillan, 2008.

Mccormack, Timothy L.H., and Helen Durham. "Aerial Bombardment of Civilians: The Current International Legal Framework." In Bombing Civilians: A Twentieth-Century History, edited by Yuki Tanaka. New York: The New Press, 2010.

Montgomery, Michael. "Horrors of Kla Prison Camps Revealed." BBC News, April $10,2009$.

"NATO Challenged over Belgrade Bombing." BBC News (October 24, 2001), http://news.bbc.co.uk/2/hi/europe/1616461.stm.

Patterson, Eric D. Ending Wars Well: Order, Justice, and Conciliation in Contemporary Post-Conflict. New Haven: Yale University Press, 2012.

Pearl, Daniel, and Robert Block. "Despite Tales, the War in Kosovo Was Savage, but Wasn't Genocide.” Wall Street Journal (December 31, 1999), http://online.wsj. com/article/SB946593838546941319.djm.html.

Pilger, John. The New Rulers of the World. London: Verso, 2002.

Pilger, John. "US and British Officials Told Us That at Least 100,000 Were Murdered in Kosovo. A Year Later, Fewer Than 3,000 Bodies Have Been Found." New Statesman (September 4, 2000), http://www.newstatesman.com/node/138456.

Priest, Dana. "Kosovo Land Threat May Have Won War." Washington Post (September 19, 1999), https://www.washingtonpost.com/wp-srv/national/daily/sept99 /airwar19.htm.

Raxhimi, Altin, Michael Montgomery, and Vladimir Karaj. "KLA Ran Torture Camps in Albania." Balkan Insight (2009), http://old.balkaninsight.com/en/main/ investigations/18064/?tpl=297.

Rengger, Nicholas. Just War and International Order: The Uncivil Condition in World Politics. Cambridge: Cambridge University Press, 2013.

Saxi, Hakon Lunde. Norwegian and Danish Defence Policy: A Comparative Study of the Post-Cold War Era. Oslo: Norwegian Institute for Defence Studies, 2010. 
Schmahling, Elmer. "More of Less Exposed Non-Combatants and Civilian Objects under the Conditions of 'Modern Warfare." In Mathematics and War, edited by Jens Hoyrup and Bernhelm Booss. Berlin: Birkhauser, 2003.

Shea, Jamie, and Wesley Clark. "Press Conference." (April 13, 1999), http://www. nato.int/kosovo/press/p990413a.htm.

Shah, Nikhil. "Depleted Uranium and International Law." Counter Currents (October 23, 2004), https://countercurrents.org/du-shah231004.htm.

Sills, Joe, Jerome C. Glenn, Elizabeth Florescu, and Theodore J. Gordon. "Environmental Crimes in Military Crimes in Military Actions and the International Criminal Court - United Nations Perspectives." Army Environmental Policy institute, April 2001.

Solana, Javier. "Press Statement." (June 10, 1999), http://www.nato.int/kosovo/ press/p990610a.htm.

Solana, Javier. "Press Statement." (March 23, 1999), http://www.nato.int/docu/ pr/1999/p99-040e.htm.

Solana, Javier. "Press Statement." (March 24, 1999), http://www.nato.int/docu/ pr/1999/p99-041e.htm.

Suhrke, Astri, Michael Barutciski, Peta Sandison, and Rick Garlock. “The Kosovo Refugee Crisis: An Independent Evaluation of Unhcr's Emergency Preparedness and Response." Geneva: UNHCR, February 2000.

Sweeney, John and Ed Vulliamy. "NATO Bombed Chinese Deliberately." New York Times (October 16, 1999), https://www.theguardian.com/world/1999/oct/17/bal kans.

Tabak, Nate. "Uranium Risks Haunt Kosovo Survivors." Deutsche Welle (November 13, 2012), http://www.dw.de/uranium-risks-haunt-kosovo-survivors/a-16 366645-0

Under Orders: War Crimes in Kosovo. New York: Human Rights Watch, 2001.

Whitney, Craig R. "U.S. Military Acted Outside NATO Framework During Kosovo Conflict, France Says." New York Times, November 11, 1999.

Wippman, David. "Kosovo and the Limits of International Law." Fordham International Law Journal 25, no. 1 (2001): 129-50. 
Yoshihara, Susan Fink. "Kosovo." In Flashpoints in the War on Terrorism, edited by Derek S. Reveron and Jeffrey Stevenson Murer. New York: Routledge, 2006.

Yuen, Y.K.J. Yeung Sik. "Human Rights and Weapons of Mass Destruction, or with Indiscriminate Effect, or of a Nature to Cause Superfluous Injury or Unnecessary Suffering." United Nations, Commission on Human Rights, June 27, 2002. 